\title{
Switching to preservative-free latanoprost: impact on tolerability and patient satisfaction
}

\author{
This article was published in the following Dove Press journal: \\ Clinical Ophthalmology \\ 26 August 2017 \\ Number of times this article has been viewed
}

\author{
Daniel Edward Robert \\ Beck' \\ Karim El-Assal' \\ Ken McGarry² \\ Nicholas Kloster Wride' \\ 'Sunderland Eye Infirmary, \\ ${ }^{2}$ Faculty of Health Sciences and \\ Wellbeing, University of Sunderland, \\ Sunderland, UK
}

\section{Dear editor}

We read with interest the article by Negrete et al. ${ }^{1}$ A recent study performed at our unit found similar results on conducting a review of tolerance to preservative-free latanoprost (Monopost) in patients who were unable to tolerate preserved formulae, and we would like to take the opportunity to share the results with you.

Notes were reviewed of 67 eyes in 35 patients started on Monopost who had shown intolerance to preserved latanoprost. It was noted that of these, only two were unable to continue the drug, demonstrating excellent tolerability. One patient stopped Monopost after 1 month, due to ocular surface discomfort. Another stopped after 7 months, as they felt the drops were the cause of their headache. The minimum follow-up was 8 months, with an average follow-up period of 15 months.

We also analyzed intraocular pressure (IOP) readings and found the mean to be $20.1 \mathrm{mmHg}$ using preserved latanoprost and $18.7 \mathrm{mmHg} 6$ weeks after switching to Monopost. A paired-sample $t$-test and Wilcoxon signed-rank test were performed, which demonstrated no significant difference between the effectiveness of the treatments $(P=0.68, P=0.117)$.

Given that these findings correlate well with the study by Negrete et al, we propose that it may not be necessary to perform an early IOP review 6 weeks after switching a patient from preserved latanoprost to Monopost, and so a patient could be followed up at their next routine glaucoma clinic visit.

This new preparation of latanoprost appears to provide, therefore, significant benefits to patients, as well as a useful therapeutic option for physicians, which is most welcome.

\section{Disclosure}

The authors report no conflicts of interest in this communication.

\section{Reference}

1. Negrete F, Lemij H, Erb C. Switching to preservative free latanoprost: impact on tolerability and patient satisfaction. Clin Ophthalmol. 2017;11:557-566. 
Dove Medical Press encourages responsible, free and frank academic debate. The content of the Clinical Ophthalmology 'letters to the editor' section does not necessarily represent the views of Dove Medical Press, its officers, agents, employees, related entities or the Clinical Ophthalmology editors. While all reasonable steps have been taken to confirm the content of each letter, Dove Medical Press accepts no liability in respect of the content of any letter, nor is it responsible for the content and accuracy of any letter to the editor.

Clinical Ophthalmology

\section{Publish your work in this journal}

Clinical Ophthalmology is an international, peer-reviewed journal covering all subspecialties within ophthalmology. Key topics include: Optometry; Visual science; Pharmacology and drug therapy in eye diseases; Basic Sciences; Primary and Secondary eye care; Patient Safety and Quality of Care Improvements. This journal is indexed on

\section{Dovepress}

PubMed Central and CAS, and is the official journal of The Society of Clinical Ophthalmology (SCO). The manuscript management system is completely online and includes a very quick and fair peer-review system, which is all easy to use. Visit http://www.dovepress.com/ testimonials.php to read real quotes from published authors. 